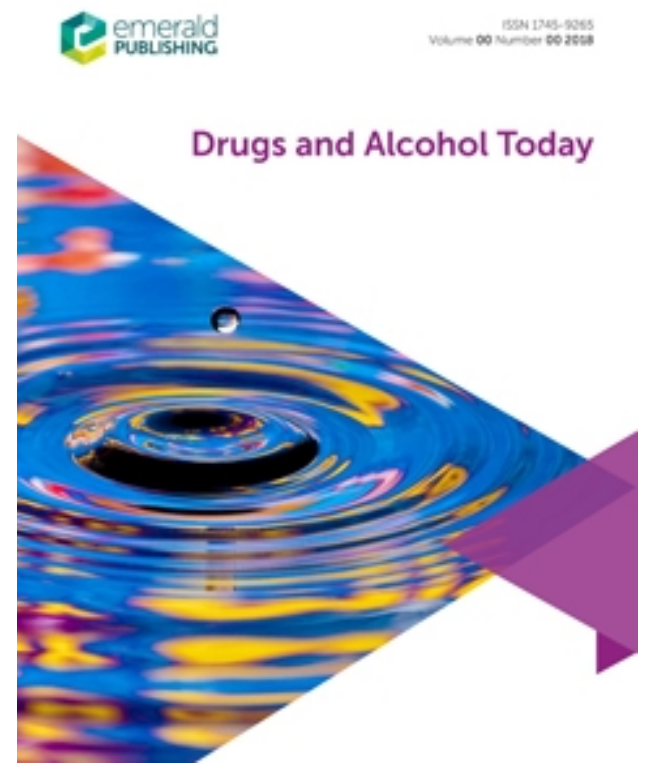

\title{
Underage drinking as a natural part of growing up: A UK study of parental beliefs.
}

\begin{tabular}{|r|l|}
\hline Journal: & Drugs and Alcohol Today \\
\hline Manuscript ID & DAT-11-2017-0058.R2 \\
\hline Manuscript Type: & Research Paper \\
\hline Keywords: & $\begin{array}{l}\text { Alcohol, Underage Drinking, Parental beliefs, Adolescents, Young people, } \\
\text { Children }\end{array}$ \\
\hline \multicolumn{2}{|l}{} \\
\hline
\end{tabular}

\section{SCHOLARONE' \\ Manuscripts}




\section{INTRODUCTION}

The prevalence of drinking under the legal age of 18 years remains high in the UK (Healey et al., 2014). Adolescent alcohol use has been linked to poor physical and mental health including depression (Edwards et al., 2014) suicide (Bagge \& Sher, 2008); poor sexual health (Vazsony et al., 2006) and a negative impact on brain development (Monti et al., 2005). The impact on education and family life can also be significant (Anderson \& Baumberg, 2006). Children's drinking behaviours are influenced by many factors including the beliefs and behaviours of their peers (Kristjansson et al., 2010) and messages in the media (Grube \& Waiters, 2005). The beliefs and behaviours of parents are known to influence the drinking behaviours of their children in direct and indirect ways. This includes the monitoring of child alcohol intake, restricting availability of alcohol, setting rules in the home, parent-child communication and modelling 'acceptable' drinking behaviour (Mynttinen, Pietilä \& Kangasniemi, 2017; Palmer \& O’Reilly, 2008; Livingston et al., 2010; Koutakis et al., 2008). Parental disapproval of alcohol intake is associated with less adolescent alcohol intake (Nash et al., 2005); and this effect occurs regardless of parent and peer drinking behaviour (Ozdemir \& Koutakis, 2015). However research exploring permissive parental attitudes is contradictory. Some studies found that a more lenient parental attitude to drinking is associated with more excessive adolescent drinking (Mares et al., 2011); whereas a systematic review and meta-analysis of 13 studies found no effect of parental permissiveness on alcohol related problems in later adolescence (Sharmin et al., 2017); although risk of bias was highlighted. If parental attitudes influence child drinking behaviour, then to influence these attitudes, there is first a need to understand parental beliefs about underage drinking and their child drinking alcohol. This in light of theoretical models of behaviour which posit that beliefs shape attitude formation (e.g. The Theory of Planned Behaviour; Ajzen, 1991). To the author's 
knowledge, there is limited evidence in the UK literature focusing specifically on parental beliefs.

Consequently, the main rationale of this study was to measure parental beliefs and whether relationships exist between these beliefs and parental reports of how much and how often they believe their children consumes alcohol. It was intended that the findings would identify potential parental beliefs to target within public health interventions.

\section{METHODS}

\section{Procedure}

Parents of children aged 11- 18 years from one of fourteen schools or colleges in the Solihull region of the West Midlands, UK, were invited to take part. Schools were initially contacted via email from staff in the local authority Public Health Department, on behalf of the researchers, using existing links with all schools in the locality. Ethical approval was obtained from Coventry University Ethics Committee. In each participating school, parents were sent a link to a secure online questionnaire via the standard school e-newsletter. The questionnaire included an information sheet and the requirement to register participant consent before taking part in the research. Either mothers or fathers were invited to contribute. Both could participate collectively as part of a single submission if they wished. Where family view-points differed, parents were asked to provide a compromised response. Parents were asked to provide one response per household, and to comment on one child (their eldest under 18 years old) only. This was in light of the fact that statistical analysis relied on the assumption that all cases are independent, which some may not have been had two responses been supplied from either parent, for the same child. Parents were reminded throughout that their responses regarding their 
beliefs about their child and young people's drinking referred to underage drinking in the 11-18 years age group only.

\section{Measures}

The anonymous online questionnaire included 31 items. This consisted of 7 demographic questions, level of agreement (Strongly Agree to Strongly Disagree) with 19 parental beliefs items about why young people drink and the impact; 2 items about how much/often they thought their child drank; 2 items about children drinking under supervision in and out of the home; and a single item about whether they talked to their child recently about alcohol. The questionnaire was designed with input from public health practitioners and commissioners, health psychologists and parents, and was also based on a review of existing measures of attitudes to underage drinking and consumption (quantity/frequency)(e.g. Engels et al., 2007), that were also designed de novo. It was piloted with a group of parents ( 4 mums and 2 dads) who were contacted via existing local public health social media channels; and feedback was sought regarding content, the number of items, scoring and ease of comprehension. The questionnaire was then revised accordingly having recognised that some items were perceived as confusing or ambiguous. For example clarification was requested about whether parents were reporting on young people in general or their own children, therefore this was made clearer. As the measure had not been used before, the psychometric properties were not known. Response options included 5-point ordinal Likert scales to report the frequency and amount they thought their child drank [i) Never drinks alcohol; ii) Occasionally drinks alcohol (e.g. once a month or a few times a year); iii) Once or twice a week; iv) Several times a week; and v) Daily]; and 
agreement with statements regarding the causes and impact of drinking on young people (on a 5-pt scale from Strongly Agree to Strongly Disagree). The Likert scale was adapted from existing measures of amount/frequency (Livingston et al., 2010 \& Engels \& Knibbe, 2000), to align with the commissioning public health department's classifications. The amount of alcohol consumed was measured in number of drinks consumed as per similar studies (e.g. Engels et al., 2007); as the pilot study indicated that parents struggled to understand and accurately calculate units.

\section{Statistical Analysis}

Data were analysed using the Statistical Package for the Social Sciences (SPSS). As a lack of normality in the data was evident from inspection of the histograms, non-parametric tests and 'Bootstrapping' were applied to the analyses to address this. Spearman's Rank correlation was used to ascertain relationships between beliefs and reports of how often and much parents thought their child drank alcohol. The Mann Whitney $\mathrm{U}$ test was used to compare groups including younger parents (25-44 years) and older parents (45-64 years) and parental responses for younger children (11-14 years) and older children (15-18 years). Where correlations between parental beliefs and alcohol consumption outcomes were significant $(p<0.05)$ with both dependent variables they were included in Bootstrapped regression analyses to explain reports of how much and how often their child drank alcohol.

\section{RESULTS}


Nine of the 14 schools invited agreed to take part. Invites to participate were sent to approximately 5097 families, and 185 families took part in the study, giving a response rate of only approximately 3.6\%. It was not possible to ascertain information about the non-responders as consent was not obtained. The 'Index of Multiple Deprivation' calculator indicated a relatively even spread of more and less deprived schools within the sample, despite the fact the locality as a whole is from a more affluent part of the UK. There were no clear differences in terms of geographical location and related socio-economic status between the schools who agreed to take part and those who did not. Therefore there was a reasonable representation across levels of deprivation, although some caution should be given in terms of generalisation.

The majority of respondents were mothers (89\%), and described themselves as of white British ethnicity (91\%). More respondents were reporting on younger (11-14 years) than older children (see table 1). There was no difference in reporting between male and female children $(51.6 \%$ male). Where parents 'Agreed' or 'Strongly Agreed' with an item on the questionnaire, the percentages are combined to indicate general agreement ('Agreed') in the following results.

\section{Parental reports of their child's alcohol consumption:}

When asked about frequency of consumption, 39.5\% of parents reported that their child had ever drunk alcohol and less than $20 \%$ of parents thought their child consumed alcohol at least weekly. Table 1 shows the breakdown of these findings. Older parents ( $45-64$ years of age) reported that their child drank significantly more often $\left(\mathrm{Z}=-2.877, \mathrm{n}_{1}=86, \mathrm{n}_{2}=98, \mathrm{p}=0.004\right)$ and in greater amounts $\left(Z=-2.794, n_{1}=83, n_{2}=98, p=0.005\right)$ than younger parents $(25-44$ years of age). There were no significant differences between older and younger parents in terms of: their attitudes and beliefs 
about their child's drinking; underage drinking in general; when they last talked to their child about alcohol. No significant differences were found between parents of younger children (11-14 years) and parents of older children ( $15-18$ years) in reporting of how much $\left(Z=-0.400, n_{1}=107, n_{2}=68, p=0.689\right)$ and how often their child drank alcohol $\left(Z=-0.067, n_{1}=110, n_{2}=69, P=0.947\right)$ and when they last talked to their child about alcohol $\left(Z=-0.141, n_{1}=99, n_{2}=63, p=0.888\right)$.

\section{Parental beliefs about young people drinking alcohol:}

Over $90 \%$ of parents believed that young people drink due to peer pressure, wanting to feel part of a group and because they enjoy experimenting. $62.6 \%$ of parents agreed that drinking by young people 'is a natural part of growing up'. There was a significant positive correlation between parental beliefs that drinking alcohol 'is a natural part of growing up' and their reports of how much their child drinks $\left(r_{s}=0.235, p=0.002\right)$ and how often they drink $\left(r_{s}=0.182, p=0.017\right)$. There were no other variables that correlated with both outcomes. Other significant correlations between parental beliefs and reported drinking outcomes are reported in table 2, including negative correlations between beliefs that drinking could lead to antisocial behaviour, addiction and experimentation with drugs; and how often they thought their child consumed alcohol.

Most parents agreed that drinking alcohol when young could lead to detrimental outcomes in terms of health, family, and society. A summary of the level of agreement in descending order under subheadings can be also be found in Table 2. More than a quarter of parents (30\%) were unsure or did not agree that 'drinking alcohol increases the risk of mental health problems'. Thirty-five per cent were unsure or did not agree that 'drinking alcohol might lead to experimentation with other drugs'. $61 \%$ of parents reported talking with their child about alcohol within the last month and, of 
those, $20 \%$ had done so within the last week. $38.4 \%$ of parents had not discussed alcohol with their children for over 6 months, if at all. $60.1 \%$ of parents reported that they felt it was easy to identify when young people are drinking. No correlation was found between how often parents report they talk to their child about alcohol and how much $\left(r_{s}=-0.069, p=0.382\right)$ and how often they report their child drinks alcohol $\left(r_{s}=-0.105, p=0.182\right)$.

\section{Multiple Regression}

Bootstrapped multiple regression analyses revealed that parental beliefs about young people's drinking predicted how often and how much they reported their child drank alcohol. The parental belief that drinking 'is a natural part of growing up', was the only belief correlated with both outcome measures, and positively predicted how often and how much parents reported their child drank (see Table 3).

\section{DISCUSSION}

In general, parents reported that their child drank no or minimal alcohol, at most consisting of one or two drinks per week in only $10 \%$ of parental reports. Over a quarter of parents were unaware of the relationship that exists between alcohol use and mental health problems, and experimentation with illegal drugs. However, the majority recognised other examples of the negative impact of drinking, and in general appeared to believe that underage drinking was a risk to health. Parents who believed drinking might lead to negative consequences such as antisocial behaviour, addiction and drug-use reported that their child drank less alcohol. Research to date suggests that although there is evidence that adolescent alcohol use acts as a gateway to drug use (Kirby \& Barry, 2012), this and associations 
with mental health, remain poorly understood. Any associations found appear to be accounted for by covariate factors relating to the individual or family in childhood, rather than a direct causal relationship (Newton-Howes \& Boden, 2016; Mohamed \& Ajmal, 2015). Therefore further research is necessary to ascertain whether beliefs about the relationship between alcohol and drugs/mental health, should form the focus of public health interventions.

In terms of how much and how often parents reported their child drank, older parents (45- 64 years) reported that their child drank more often, and in greater amounts than younger parents (25 44 years). It is possible that this reflects older parents with children over 18 years whose behaviour influences their younger siblings. However, if this was the case it was surprising to note no significant differences were found when comparing reports for children of younger school age (11-14 years) with older school age (15-18 years).

The belief that young people drinking alcohol is a 'natural part of growing up' was held by almost two thirds of parents. This belief positively predicted how often and how much parents reported their child drank alcohol. In other words the more strongly parents believed drinking is a natural part of growing up, the more they reported their child drank. Therefore holding this belief may be associated with increased alcohol consumption in adolescence. Given that parents tend to underestimate rather than overestimate children's consumption, and there is a positive correlation between parent and child reports (Livingston et al., 2010), this association may warrant further investigation. However, as actual child reports of their consumption were not measured, any direction of causality is unclear. Knowing that your child drinks alcohol may result in parents reporting 
a belief that this is a normal part of growing up, in order to justify their child's behaviour, and their role in 'allowing' this.

The belief that i) drinking alcohol when young is damaging and can have a negative impact on many areas of life, is somewhat contrary to the belief that ii) it is a normal part of growing up, yet many parents seem to hold these two views simultaneously. One possible explanation is that parents hold both public 'outfacing' beliefs and private 'inward facing' beliefs (Jayne et al., 2012). Outfacing beliefs are driven by social desirability effects, and therefore may reflect what parents know they should believe from recommended guidance in order to be a 'good parent'. In this case, outfacing beliefs may reflect wider society's concerns about the harmful health effects of underage drinking. Nonetheless, parents may simultaneously hold a private 'inward' facing belief that drinking is a natural part of growing up, which may result from their own experience and what they witness other parents condone (social norms). Indeed, Crawford \& Novak (2006) argue that parents experience a discord between the desire to keep their children safe from physical harm (health risks of underage drinking) as well as social harm (if they go against societal norm of underage drinking). Parents may experience unease as a result of these conflicting beliefs, also termed 'cognitive dissonance' (Festinger, 1957), which describes the psychological state of distress when an individual holds conflicting beliefs. To overcome this, a new belief is formed which allows individuals to hold these contradictory beliefs simultaneously. For example parents could recognise the potential negative impact, but consider these risks to be rare compared to the high rate of 'normal' teenage drinking. This could allow them to condone their child's drinking due to the belief that their child will only ever experiment at this age (because it is 'normal') and they are unlikely to encounter problems. 
Parental approval and permissiveness of alcohol is subject to influence and direction from other parents in their social networks (Labrie et al., 2011). Indeed, one study found that parents experienced increasing pressures to supply alcohol to their children, as a result of perceptions regarding the social norms of drinking amongst their child's peers (Gilligan \& Kypri, 2012). The 'Majority Fallacy' describes the tendency to exaggerate estimations of how much we think peers drink or other parents allow their child to drink in order to validate our own, or our child's drinking (Makela, 1997). In support of this, recent research demonstrates that adults perceive the wider community as more accepting of underage drinking than they are (Jones \& Francis, 2015), further justifying their choices safe in the knowledge they are on the comparatively conservative side. This may allow parents to further increase the normality of their child's drinking but see the risks as rare and something that will happen to others and not themselves. A longitudinal study of 494 youths and their parents, provides further support for this hypothesis since parents who encountered their child drinking tended to adapt their own beliefs regarding youth drinking to be more lenient and permissive, rather than trying to change their child's behaviour (Glatz et al., 2012). The literature explores the notion of a liminal and transitory stage of drinking in adolescence, wherein alcohol consumption is deemed more acceptable and assumed to be short-lived (Berendi, Jones \& Andrews, 2016). There is evidence that college students believe drinking is a rite of passage (Lewis \& Hession, 2012), however limited exploration of this belief in parents. If parents are adapting their beliefs to accommodate the social norm of underage drinking, and furthermore are engaging in strategies to reduce their concern about this behaviour, this may result in parents exhibiting more permissive parenting behaviours around alcohol consumption. This could in turn result in a further increase in underage drinking and exacerbate a vicious cycle of permissive social norms and increased drinking. 
Although drinking in school age children is reported to be in decline (Fuller \& Hawkins, 2013), the amounts reported in this study are still substantially less than current research would suggest (Bellis et al., 2009). Parents may under-report how much their child drinks for a number of reasons, including a lack of awareness or social desirability effects (LaBrie et al., 2014). Contrary to expectation, this study also found that parents of younger children did not report that their child drank less than older children. This contradicts the finding that weekly drinking increases with school age (Currie et al., 2008). Equally, the finding that older parents reported their child drank greater amounts and more often is interesting, and appears to contradict research to suggest that older parents hold more conservative beliefs (Jones \& Francis, 2015). There was no correlation between parental age and beliefs about underage drinking and no differences between older and younger parents, in terms of when they last talked to their child about alcohol. As such neither beliefs nor talking about alcohol provide possible explanations for our finding. Alternative reasons include more life experience, their own past experiences of drinking alcohol when they were young, confidence to report honestly or less awareness or exposure to the harms of alcohol for example via social media more commonly used by younger parents. Recent research suggests that middle age and older adults tend to drink more frequently than younger people (Alcohol Concern, 2015). Therefore, these parents may also hold beliefs about their child's drinking that correspond to their own current drinking behaviour.

\section{Implications \& Recommendations}


Children may be receiving mixed messages in the home if the dually held beliefs identified in this study are commonplace (Eadie et al., 2010). On the one hand, they receive messages from parents, school and the media that alcohol can be damaging to health and wellbeing. On the other hand, parents may present a message that underage drinking is to be expected. Addressing parental beliefs about normalised drinking practice in young people may be an important consideration for public health campaigns (Smit et al., 2008). Research suggests parents may not recognise that public health campaigns and messages are aimed at them, therefore it is essential the target audience is helped to perceive themselves as such (Jones, Andrews \& Berry, 2016). Historically, Public Health has focused heavily on information giving. The results of this exploratory study suggest that parents have a relatively good understanding of the harmful effects of drinking on young people. What may be needed are interventions to challenge the normalisation of underage drinking.

'Frames' refer to the way information is presented, triggering our existing concepts and beliefs on a subject, which may be biased, helpful or inaccurate. 'Re-framing' refers to methods designed to present information in a new way, in order to adapt these pre-existing ideas, enabling new assumptions to be formed. An example of re-framing in the field of obesity found that existing frames focused on will-power and the individual, further stigmatising obesity. By re-framing the focus onto the environmental, societal and political rather than individual behavioural context (e.g. adapting the environment to make health-enhancing choices easier to make), the authors propose public health can better support positive changes to health (e.g. Dorfman \& Wallack, 2007). A 'framing-reframing' approach could be applied to public health messages, acknowledging that beliefs that underage drinking is a normal part of growing up are commonplace and understandable, 
however demonstrating this belief in terms of permissiveness and parent-child communication can have a significant negative impact on adolescent drinking behaviour long-term.

\section{Limitations of this study}

There are a number of limitations with the study. The sample is relatively small as a result of a low response rate, predominantly white British and mainly consists of the views of mothers. It is unclear if the views were the collective view of both parents' combined or just mothers, and it was not possible to access demographic information about the non-responders who may have differed from responders. It would have been helpful to ascertain whether parents had any children over 18 years of age, for whom they had already experienced the impact of underage and adolescent drinking, which may have influenced their beliefs in relation to later siblings. We cannot infer from these findings that these beliefs directly affect young people's drinking behaviour, as this was not measured, and parental reporting may be subject to error and social desirability effects. However, research suggests that parental reporting is likely to be under rather than over-inflated (Engels et al., 2007; Guilamo-Ramos et al., 2006), therefore actual drinking in young people is likely to be greater than reported here. Measuring parental drinking behaviour would also have enabled a better understanding of how their beliefs are formed.

The questionnaire was designed de novo and therefore lacked psychometric rigour. The items measuring drinking frequency would have benefitted from separating out 'occasional' with 'monthly' drinking, as patterns may have differed significantly, affecting the findings. The definition of "binge drinking' used in this study was ' 6 or more drinks on one occasion or heavy drinking for days or weeks 
followed by no drinking'. Although used by the local public health department, it is not in line with the current national consensus of consuming 5 drinks in adolescents (Degenhardt et al., 2013). The latter part of the definition also includes what constitutes 'problem' rather binge drinking, and should have been a separate item.

This study would have benefited from a qualitative exploratory approach to better explore i) novel parental beliefs about underage drinking; ii) whether parents feel their attitudes and beliefs impact on their child's drinking behaviour, and in what ways; and iv) the basis for which they estimate their child's drinking behaviour. The addition of qualitative research to explore the dual belief concept, the role of cognitive dissonance, and how parents interpreted the item 'Drinking is a natural part of growing up' would also have enhanced the findings and conclusions drawn.

\section{Conclusions}

To the authors knowledge this is the first study to report the widespread and potentially detrimental parental belief that underage drinking is a natural part of growing up, alongside the common dual belief that underage drinking poses risks of harm. Future research is necessary to explore in greater depth how and why these beliefs are formed and the impact long-term on parental permissiveness and adolescent drinking behaviour.

\section{REFERENCES}


1. Ajzen, I. (1991). "The theory of planned behavior". Organizational Behavior and Human Decision Processes. 50 (2): 179-211. doi:10.1016/0749-5978(91)90020-T.

2. Alcohol Concern. (2015), "Statistics on Alcohol". Available from: http://www.alcoholconcern.org.uk/help-and-advice/statistics-on-alcohol/. (Accessed July 2015).

3. Anderson, P. \& Baumberg, B. (2006), “Alcohol in Europe. A Public Health Perspective. A Report for the European Commission". London: Institute of Alcohol Studies. Available from: http://ec.europa.eu/health/ph_determinants/life_style/alcohol/documents/alcohol_europe.p df (Accessed March 2015).

4. Bagge, C.L. \& Sher, K.J. (2008), “Adolescent alcohol involvement and suicide attempts: toward the development of a conceptual framework". Clinical Psychology Review, Vol. 28 No. 8, pp. 1283-96. DOI: 10.1016/j.cpr.2008.06.002

5. Bellis, M.A., Phillips-Howard, P.A., Hughes, K., Hughes, S., Cook, P.A., Morleo, M., Hannon, K., Smallthwaite, L. \& Jones, L. (2009), “Teenage drinking, alcohol availability and pricing: a crosssectional study of risk and protective factors for alcohol-related harms in school children". BMC Public Health, Vol. 9, pp. 380. DOI: 10.1186/1471-2458-9-380.

6. Berends, S.C. \& Jones, Andrews, K. (2016), “Adolescent drinking, social identity, and parenting for safety: Perspectives from Australian adolescents and parents”. Health \& Place, Vol. 38, pp. 22-29. DOI: 10.1016/j.healthplace.2015.12.006 
7. Crawford, L.A. \& Novak, K.B. (2006), "Alcohol abuse as a rite of passage: The effect of beliefs about alcohol and the college drinking experience on undergraduates' drinking". Journal of Drug Education, Vol. 36 No. 3, pp. 193-212. DOI: 10.2190/F0X7-H765-6221-G742

8. Currie, C., Gabhainn, S.N, Godeau, E., Roberts, C., Smith, R., Currie, D., Picket, W., Richter, M., Morgan, A. \& Barnekow, V. (Eds). (2008), Inequalities in young people's health: HBSC International report from the 2005/2006 survey. Edinburgh: World Health Organisation Regional Office for Europe.

9. Degenhardt, L., O'Loughlin, C., Swift, W., Romaniuk, H., Carlin, J., Coffey, C., Hall, W., Patton, G. (2013). "The persistence of adolescent binge drinking into adulthood: findings from a 15year prospective cohort study". BMJ open, Vol. 3 No. 8, pp. e003015. doi:10.1136/bmjopen2013-003015

10. Dorfman, L. \& Wallack, L. (2007). “Moving Nutrition Upstream: The Case for Reframing Obesity". Journal of Nutrition Education and Behavior, Vol 39, No 2, pp. S45-S50. DOI: 10.1016/j.jneb.2006.08.018.

11. Eadie, D., MacAskill, S., Brooks, O., Heim, D., Forsyth, A. \& Punch, S. (2010), Pre-teens learning about alcohol, Drinking and family contexts. Joseph Rowntree Foundation.

12. Edwards, A.C., Heron, J., Dick, D.M., Hickman, M., Lewis, G., Macleod, J. \& Kendler, K.S. (2014), "Adolescent alcohol use is positively associated with later depression in a populationbased UK cohort". Journal of Studies on Alcohol and Drugs, Vol. 75 No. 5, pp. 758-765. DOI: $10.1007 / \mathrm{s} 00787-014-0600-5$ 
13. Engels, R.C.M.E., Van Der Vorst, H., Dekovic, M. \& Meeus, W. (2007), “Correspondence in collateral and self-reports on alcohol consumption: A within family analysis". Addictive Behaviors, Vol. 32 No. 5, pp. 1016-1030. DOI:10.1016/j.addbeh.2006.07.006

14. Engels, R. C. M. E., \& Knibbe, R. A. (2000). "Alcohol use and intimate relationships in adolescence: When love comes to town". Addictive Behaviors, Vol. 25 No. 3, 435-439. DOI: https://doi.org/10.1016/S0306-4603(98)00123-3.

15. Festinger, L. (1957), A Theory of cognitive dissonance. Stanford, CA: Stanford University Press.

16. Fuller, E. \& Hawkins, V. (2013), Smoking, drinking and drug use amongst young people in England in 2013. A survey for the Health \& Social Care Information Centre (HSCIC), carried out by NatCen Social Research and the National Foundation for Educational Research. (Accessed June 2015).

17. Gilligan, C. \& Kypri, K. (2012), “Parent attitudes, family dynamics and adolescent drinking: qualitative study of the Australian parenting guidelines for adolescent alcohol use". BMC Public Health, Vol. 12, pp. 491. DOI: 10.1186/1471-2458-12-491.

18. Glatz, T., Stattin, H. \& Kerr, M.A. (2012), "Test of Cognitive Dissonance Theory to Explain Parents' Reactions to Youths' Alcohol Intoxication". Family Relations, Vol. 61 No. 4, pp. 629 641. DOI: 10.1111/j.1741-3729.2012.00723

19. Grube, J.W. \& Waiters, E. (2005), "Alcohol in the Media: Content and Effects on Drinking Beliefs and behaviors Among Youth". Adolescent Medicine Clinics, Vol. 16 No. 2, pp. 327-43. DOI: 10.1016/j.admecli.2005.02.005 
20. Guilamo-Ramos, V., Jaccard, J., Turrisi, R., Johansson, M., \& Bouris, A. (2006). "Maternal Perceptions of Alcohol Use by Adolescents Who Drink Alcohol". Journal of Studies on Alcohol, $67(5), 730-737$.

21. Healey, C., Rahman, A., Faizal, M. \& Kinderman, P. (2014), “Underage drinking in the UK: Changing trends, impact and interventions. A rapid evidence synthesis". International Journal of Drug Policy, Vol. 25 No. 1, pp. 124-132. DOI: 10.1016/j.drugpo.2013.07.008

22. Jayne, M., Valentine, G. \& Gould, M. (2012), “Family life and alcohol consumption: The transmission of 'public' and 'private' drinking cultures". Drugs: Education, Prevention and Policy, Vol. 19 No. 3, pp. 192-200. DOI:10.3109/09687637.2011.640720

23. Jones, S.C., Andrews, K. and Berry, N. (2016), "Lost in translation: a focus group study of parents' and adolescents' interpretations of underage drinking and parental supply". BMC public health. Vol. 16 No 1, pp. 561. DOI: 10.1186/s12889-016-3218-3.

24. Jones, S.C., Francis, K. (2015), "Supply of alcohol to underage drinkers: misperceptions of community norms". Social Science \& Medicine, Vol. 147, pp. 158-62. DOI: 10.1016/j.socscimed.2015.10.067.

25. Kirby, T. \& Barry, A. E. (2012), "Alcohol as a Gateway Drug: A Study of US 12th Graders". Journal of School Health, Vol. 82, pp. 371-379. DOI: 10.1111/j.1746-1561.2012.00712.

26. Koutakis, N., Stattin, H. \& Kerr, M. (2008), “Reducing youth alcohol drinking through a parenttargeted intervention: the Örebro Prevention Program". Addiction, Vol. 103 No. 10, pp. 16291637. DOI: 10.1111/j.1360-0443.2008.02326.x. 
27. Kristjansson, A.L., Sigfusdottir, I.D., James, J.E., Allegrante, J.P. \& Helgason, A.R. (2010), “Perceived parental reactions and peer respect as predictors of adolescent cigarette smoking and alcohol use". Addictive Behaviors, Vol. 35 No. 3, pp. 256-259. DOI:10.1016/j.addbeh.2009.10.002

28. LaBrie, J.W., Hummer, J.F., Lac, A., Ehret, P.J. \& Kenney, S.R. (2011), “Parents know best, but are they accurate? Parental normative misperceptions and their relationship to students' alcohol related outcomes". Journal of Studies on Alcohol and Drugs, Vol. 72 No. 4, pp. 521529. DOI: 10.15288/jsad.2011.72.521.

29. LaBrie, J.W., Napper, L.E. \& Hummer, J.F. (2014), “Normative feedback for parents of college students: Piloting a parent based intervention to correct misperceptions of student's alcohol use and other parent's approval of drinking". Addictive Behaviors, Vol. 39 No. 1, pp. 107-113. DOI: 10.1016/j.addbeh.2013.08.036

30. Lewis, T.P., \& Hession, C. (2012), "Alcohol Use: From Childhood Through Adolescence". Journal of Pediatric Nursing, Vol. 27 No. 5, pp. e50-e58. DOI: 10.1016/j.pedn.2012.01.003

31. Livingston, J.A., Testa, M., Hoffman, J.H. \& Windle, M. (2010), “Can parents prevent heavy episodic drinking by allowing teens to drink at home?" Addictive Behaviors, Vol. 35 No. 12, pp. 1105-1112. DOI: 10.1016/j.addbeh.2010.08.005

32. Makela, K. (1997), "Drinking, the majority fallacy, cognitive dissonance and social pressure". Addiction, Vol. 92 No. 6, pp. 729. DOI: 10.1111/j.1360-0443.1997.tb02939. 
33. Mares, S.H.W., van der Vorst, H., Engels, R. \& Lichtwarck-Aschoff, A. (2011), "Parental alcohol use, alcohol-related problems, and alcohol-specific attitudes, alcohol-specific communication, and adolescent excessive alcohol use and alcohol-related problems: an indirect path model". Addictive Behaviors, Vol. 36 No. 3, pp. 209-216. DOI: 10.1016/j.addbeh.2010.10.013

34. Mohamed, S., \& Ajmal, M. 2015, "Multivariate analysis of binge drinking in young adult population: Data analysis of the 2007 Survey of Lifestyle, Attitude and Nutrition in Ireland", Psychiatry \& Clinical Neurosciences, Vol. 69 No. 8, pp. 483-488. DOI: 10.1111/pcn.12284.

35. Monti, P.M., Miranda, R., Nixon, K., Sher, K.J., Swartzwelder, H.S., Tapert, S.F., White, A. \& Crews, F.T. (2005), “Adolescence: Booze, brains and behaviour". Alcoholism, Clinical and Experimental Research, Vol. 29 No. 2, pp. 207-220.

DOI: 10.1097/01.ALC.0000153551.11000.F3

36. Mynttinen, M., Pietilä, A. \& Kangasniemi, M. (2017), “What Does Parental Involvement Mean in Preventing Adolescents' Use of Alcohol? An Integrative Review". Journal of Child \& Adolescent Substance Abuse, Vol. 26 No. 4, pp. 338-351.

DOI:10.1080/1067828X.2017.1306471

37. Nash, S.G., McQueen, A., Bray, J.H. (2005), "Pathways to adolescent alcohol use: familyenvironment, peer influence, and parental expectations". Journal of Adolescent Health, Vol. 37 No. 1, pp. 19-28. DOI: 10.1016/j.jadohealth.2004.06.004 
38. Newton-Howes, G., \& Boden, J. 2016, "Relation between age of first drinking and mental health and alcohol and drug disorders in adulthood: evidence from a 35-year cohort study", Addiction, Vol. 111 No. 4, pp. 637-644. DOI: 10.1111/add.13230

39. Özdemir, M., \& Koutakis, N. (2016), “Does promoting parents' negative attitudes to underage drinking reduce adolescents' drinking? The mediating process and moderators of the effects of the Örebro Prevention Programme". Addiction, Vol. 111, pp. 263-271. DOI: 10.1111/add.13177.

40. Palmer, D. \& O'Reilly, G. (2008), Young People, Alcohol and Drugs. Dublin: Juvenile Mental Health Matters.

41. Sharmin, S., Kypri, K., Khanam, M., Wadolowski, M., Bruno, R., Attia, J., Holliday, E., Palazzi, K. \& Mattick, R. P. (2017), “Effects of parental alcohol rules on risky drinking and related problems in adolescence: Systematic review and meta-analysis". Drug and Alcohol Dependence, Vol. 178, pp. 243-256, DOI: 10.1016/j.drugalcdep.2017.05.011.

42. Smit, E., Verdrmen, J., Monshouwer, K. \& Smit, F. (2008), “Family interventions and their effect on adolescent alcohol use in general populations; a meta-analysis of randomized controlled trials". Drug and Alcohol Dependence, Vol. 97 No. 3, pp. 195-206. DOI: 10.1016/j.drugalcdep.2008.03.032.

43. Vazsonyi, A.T., Trejos-Castillo, E. \& Huang, Li. (2006), "Risky sexual behaviors, alcohol use, and drug use: a comparison of Eastern and Western European adolescents". Journal of Adolescent Health, Vol. 39 No. 5, pp. 753.e1-11. DOI:10.1016/j.jadohealth.2006.05.008 
Drugs and Alcohol Today

Page 22 of 31

$$
\begin{aligned}
& 1 \\
& 2 \\
& 3 \\
& 4 \\
& 5 \\
& 6 \\
& 7 \\
& 8 \\
& 9 \\
& 10 \\
& 11 \\
& 12 \\
& 13 \\
& 14 \\
& 15 \\
& 16 \\
& 17 \\
& 18 \\
& 19 \\
& 20 \\
& 21 \\
& 22 \\
& 23 \\
& 24 \\
& 25 \\
& 26 \\
& 27 \\
& 28 \\
& 29 \\
& 30 \\
& 31 \\
& 32 \\
& 33 \\
& 34 \\
& 35 \\
& 36 \\
& 37 \\
& 38 \\
& 39 \\
& 40 \\
& 41 \\
& 42 \\
& 43 \\
& 44 \\
& 45 \\
& 46 \\
& 47 \\
& 48 \\
& 49 \\
& 50 \\
& 51 \\
& 52 \\
& 53 \\
& 54 \\
& 55 \\
& 56 \\
& 57 \\
& 59
\end{aligned}
$$


Table 1: Parental reported frequency and amount of child's alcohol consumption

\begin{tabular}{|l|l|l|l|l|l|}
\hline Response option & $\begin{array}{l}\text { \% Total } \\
\text { sample } \\
(\mathrm{n}=185)\end{array}$ & $\begin{array}{l}\text { \% Older } \\
\text { parents (45- } \\
64) \mathrm{n}=99\end{array}$ & $\begin{array}{l}\text { \% Younger } \\
\text { parents (25- } \\
44) \mathrm{n}=86\end{array}$ & $\begin{array}{l}\text { \% Parents of } \\
\text { younger } \\
\text { children } \\
\text { (age 11-14) } \\
\mathrm{n=110}\end{array}$ & $\begin{array}{l}\text { \% Parents of } \\
\text { older } \\
\text { children } \\
\text { (age 15-18) } \\
\mathrm{n=69}\end{array}$ \\
\hline $\begin{array}{l}\text { Frequency of alcohol } \\
\text { consumption }\end{array}$ & & & & & \\
\hline Never & 60 & 50.5 & 70.9 & 66 & 60.9 \\
\hline Occasionally & 31.9 & 37.4 & 25.6 & 33.6 & 29.0 \\
\hline Once or twice a week & 5.4 & 9.1 & 1.2 & 3.6 & 8.7 \\
\hline Several times a week & 2.2 & 2.0 & 2.3 & 2.7 & 1.4 \\
\hline Bingeing pattern ${ }^{b}$ & 0 & 0 & 0 & 0 & 0 \\
\hline $\begin{array}{l}\text { Don't know } \\
\text { missing }\end{array}$ & 0 & 0 & 0 & 0 & 0 \\
\hline $\begin{array}{l}\text { Number of alcoholic } \\
\text { drinks consumed per } \\
\text { week }\end{array}$ & 0.5 & 1.0 & 0 & 0 & 0 \\
\hline No alcohol & 81.6 & 75.8 & 88.4 & 80.0 & 84.1 \\
\hline 1 or 2 drinks & 10.8 & 14.1 & 7.0 & 13.6 & 7.2 \\
\hline 3 or 4 drinks & 2.2 & 3.0 & 1.2 & 1.8 & 2.9 \\
\hline 5 or 6 drinks & 1.1 & 2.0 & 0 & 1.8 & 2.9 \\
\hline More than 6 drinks & 2.2 & 4.0 & 0 & 0 & 1.4 \\
\hline Don't know & 0 & 0 & 0 & 0 & 1.4 \\
\hline missing & 2.2 & 1 & 3.5 & 2.7 & \\
\hline
\end{tabular}

ae.g. once a month or a few times a year

be.g. 6 or more standard drinks in one occasion or heavy drinking for days or weeks followed by no drinking for days or weeks (based on local public health department definition) 
Table 2. The percentage of parents who agreed with statements about the impact of drinking on young people, in descending order of agreement.

\begin{tabular}{|c|c|c|c|}
\hline \multirow[t]{2}{*}{ Item on the questionnaire } & \multirow{2}{*}{$\begin{array}{l}\text { \% of parents } \\
\text { who 'Strongly } \\
\text { Agreed' or } \\
\text { 'Agreed' }\end{array}$} & \multicolumn{2}{|c|}{$\begin{array}{c}\text { Spearman's rank } \\
\text { correlation with parental } \\
\text { reports of }\end{array}$} \\
\hline & & $\begin{array}{l}\text { How often } \\
\text { child drank }\end{array}$ & $\begin{array}{l}\text { How much } \\
\text { child drank }\end{array}$ \\
\hline \multicolumn{4}{|l|}{ Reasons why young people drink } \\
\hline Peer pressure & 94.1 & 0.54 & .10 \\
\hline Young people like experimenting & 94 & 0.03 & 0.12 \\
\hline To feel accepted or part of a group & 91.8 & 0.10 & 0.11 \\
\hline To feel more grown up & 88.9 & 0.06 & 0.09 \\
\hline Young people like to take risks & 74 & -0.08 & -0.00 \\
\hline It's a natural part of growing up & 62.6 & $0.18^{*}$ & $0.24^{* *}$ \\
\hline For the physical effects of alcohol & 61 & 0.00 & 0.03 \\
\hline To block out problems & 48 & $-0.19 *$ & -0.10 \\
\hline \multicolumn{4}{|l|}{ Impact of drinking } \\
\hline $\begin{array}{l}\text { Drinking can lead to unprotected sex, increasing the } \\
\text { risk of sexually transmitted infections and } \\
\text { pregnancy }\end{array}$ & 97.6 & -0.06 & 0.01 \\
\hline Drinking can lead to violent behaviour & 95.2 & -0.07 & -0.05 \\
\hline $\begin{array}{l}\text { Drinking alcohol increases the risk of a range of } \\
\text { serious physical illnesses and accidents }\end{array}$ & 94.1 & --0.12 & -0.09 \\
\hline $\begin{array}{l}\text { Drinking alcohol can cause problems in family } \\
\text { relationships }\end{array}$ & 92.3 & -0.18 & -0.13 \\
\hline $\begin{array}{l}\text { Drinking causes anti-social behaviour in young } \\
\text { people }\end{array}$ & 91.2 & $-0.17^{*}$ & -0.09 \\
\hline $\begin{array}{l}\text { Drinking alcohol can lead to addiction and } \\
\text { dependency }\end{array}$ & 84.7 & $-0.21 * *$ & -0.09 \\
\hline $\begin{array}{l}\text { Drinking is often related to peer pressure and can } \\
\text { be associated with bullying and pressure to engage } \\
\text { in other risky behaviours }\end{array}$ & 80.6 & -0.07 & -0.04 \\
\hline $\begin{array}{l}\text { Drinking alcohol increases the risk of mental health } \\
\text { problems }\end{array}$ & 68.8 & -0.05 & 0.05 \\
\hline $\begin{array}{l}\text { Drinking alcohol might lead to experimentation with } \\
\text { other drugs }\end{array}$ & 65.1 & $-0.19 *$ & -0.12 \\
\hline Drink-driving is a significant risk in this age group & 59.7 & -0.06 & -0.06 \\
\hline Drinking alcohol is associated with criminal activity & 53.8 & -0.04 & -0.02 \\
\hline
\end{tabular}

${ }^{*} p<0.05,{ }^{* *} p<0.01$ 
Table 3: Bootstrapped regression analysis of parental beliefs on parental reports of how often and how much their child drank alcohol

\begin{tabular}{|c|c|c|c|c|c|}
\hline DV & & $B$ & \multicolumn{2}{|c|}{$95 \% \mathrm{Cl}(\mathrm{B})$} & Adj. $R^{2}$ \\
\hline \multirow{2}{*}{$\begin{array}{l}\text { How often } \\
\text { child drank }\end{array}$} & Constant & 1.11 & 0.80 & 1.44 & \multirow[b]{2}{*}{0.02} \\
\hline & $\begin{array}{l}\text { Drinking is a } \\
\text { natural part of } \\
\text { growing up }\end{array}$ & $0.12^{*}$ & 0.02 & 0.21 & \\
\hline \multirow{2}{*}{$\begin{array}{l}\text { How much } \\
\text { child drunk }\end{array}$} & Constant & 0.71 & 0.44 & 0.92 & \multirow[b]{2}{*}{0.44} \\
\hline & $\begin{array}{l}\text { Drinking is a } \\
\text { natural part of } \\
\text { growing up }\end{array}$ & $0.17^{* *}$ & 0.08 & 0.27 & \\
\hline
\end{tabular}

${ }^{*} p<0.05 ; * * p<0.01$ Bootstrapping based on 1000 samples. 
Drugs and Alcohol Today

Page 26 of 31

$$
\begin{aligned}
& 1 \\
& 2 \\
& 3 \\
& 4 \\
& 5 \\
& 6 \\
& 7 \\
& 8 \\
& 9 \\
& 10 \\
& 11 \\
& 12 \\
& 13 \\
& 14 \\
& 15 \\
& 16 \\
& 17 \\
& 18 \\
& 19 \\
& 20 \\
& 21 \\
& 22 \\
& 23 \\
& 24 \\
& 25 \\
& 26 \\
& 27 \\
& 28 \\
& 29 \\
& 30 \\
& 31 \\
& 32 \\
& 33 \\
& 34 \\
& 35 \\
& 36 \\
& 37 \\
& 38 \\
& 39 \\
& 40 \\
& 41 \\
& 42 \\
& 43 \\
& 44 \\
& 45 \\
& 46 \\
& 47 \\
& 48 \\
& 49 \\
& 50 \\
& 51 \\
& 52 \\
& 53 \\
& 54 \\
& 55 \\
& 56 \\
& 57 \\
& 59
\end{aligned}
$$




\section{Response to second revision Fulton et al.}

\begin{tabular}{|c|c|c|}
\hline & Reviewer comments & Author amendments \\
\hline 1 & $\begin{array}{l}\text { I think the rationale could } \\
\text { be more clearly related to } \\
\text { the background literature. I } \\
\text { agree that there is a need } \\
\text { to understand parental } \\
\text { 'beliefs' or attitudes } \\
\text { towards adolescent } \\
\text { drinking, but this needed to } \\
\text { be more clearly justified. I } \\
\text { think it also needs to be } \\
\text { clearer what is meant by } \\
\text { beliefs and why beliefs } \\
\text { were chosen over attitudes } \\
\text { for example. }\end{array}$ & $\begin{array}{l}\text { We have attempted to explain the rationale } \\
\text { more clearly now, in that there is a paucity of } \\
\text { research looking specifically at parental beliefs } \\
\text { about underage drinking, and as beliefs are } \\
\text { known to shape attitudes (theory of planned } \\
\text { behaviour), and attitudes are influence child } \\
\text { drinking, there is a rationale for further focus } \\
\text { on beliefs in order to design suitable } \\
\text { interventions to target these. }\end{array}$ \\
\hline 2 & $\begin{array}{l}\text { The methodology does not } \\
\text { fit well with the exploratory } \\
\text { nature that seems to be } \\
\text { implied by the rationale. } \\
\text { This type of enquiry may } \\
\text { have been better suited to a } \\
\text { qualitative methodology. }\end{array}$ & $\begin{array}{l}\text { Authors agree it is not appropriate to call it an } \\
\text { exploratory study given the methodology, } \\
\text { therefore this has been removed. } \\
\text { A sentence has been added to the limitations } \\
\text { about the value of having started with a qual. } \\
\text { exploratory approach looking at how parental } \\
\text { beliefs impact on child drinking in the view of } \\
\text { the parent, and the evidence they use to justify } \\
\text { how much they believe their child drinks. }\end{array}$ \\
\hline 3 & $\begin{array}{l}\text { The main issue for me is the } \\
\text { questionnaire. It is difficult } \\
\text { to understand how the } \\
\text { questionnaire was } \\
\text { 'designed', and the } \\
\text { theoretical framework upon } \\
\text { which it is based. There is } \\
\text { no clear reference to any } \\
\text { theory and items are not } \\
\text { clearly justified or related to } \\
\text { any previous literature, } \\
\text { although the consultation } \\
\text { was mentioned. More } \\
\text { information around this } \\
\text { would have been useful. }\end{array}$ & $\begin{array}{l}\text { We were somewhat restricted in the design of } \\
\text { the questionnaire as the items were dictated by } \\
\text { the public health dept who commissioned the } \\
\text { study, and it was therefore designed de novo. It } \\
\text { was not deemed appropriate to base the } \\
\text { questionnaire on a theoretical framework, to } \\
\text { my understanding. The questionnaire was } \\
\text { however designed based on an adaption of } \\
\text { existing parental measures of attitudes about } \\
\text { underage drinking, and measures of perceived } \\
\text { child drinking consumption (e.g. engels et al., } \\
\text { 2007, which were also designed de novo); with } \\
\text { input from health psychologists/researchers. So } \\
\text { we have added this ref and this explanation. It } \\
\text { is also now a listed limitation. }\end{array}$ \\
\hline 4 & $\begin{array}{l}\text { It is also stated that there } \\
\text { were } 40 \text { items and there are }\end{array}$ & $\begin{array}{l}\text { It should not state there are } 40 \text { items, the } \\
\text { authors apologise for this error. There were } 31\end{array}$ \\
\hline
\end{tabular}




\begin{tabular}{|c|c|c|}
\hline & $\begin{array}{l}19 \text { items reported in Table } \\
2 . \text { Therefore it is difficult to } \\
\text { follow why these items are } \\
\text { included and what } \\
\text { happened to the other } 21 . \\
\text { Is it that there are } \\
\text { subscales?, in which case } \\
\text { why is this not stated and } \\
\text { internal consistency } \\
\text { reported, or are they all } \\
\text { single item? }\end{array}$ & $\begin{array}{l}\text { questions used for this study so we have } \\
\text { amended the number to this. The other } 9 \text { items } \\
\text { were specific questions about knowledge about } \\
\text { alcohol services locally and therefore not } \\
\text { relevant to a wider audience. } 19 \text { items are } \\
\text { included in table } 2 \text {. There were a further } 7 \\
\text { demographic questions, } 2 \text { questions about how } \\
\text { much/often they thought their child drank, } 2 \\
\text { questions about drinking under supervision, } \\
\text { and one about whether they talked recently to } \\
\text { their child about alcohol. We have more } \\
\text { explicitly listed this now to be clear. There were } \\
\text { no subscales, rather we grouped items at the } \\
\text { point of analysis into the two groups listed in } \\
\text { table } 2 \text {. }\end{array}$ \\
\hline 5 & $\begin{array}{l}\text { The frequency measure is } \\
\text { described in a little more } \\
\text { detail but it is not clear } \\
\text { what the Likert scale was } \\
\text { based on. The examples of } \\
\text { frequency could have been } \\
\text { more consistent with other } \\
\text { adolescent alcohol use } \\
\text { measures. It is not clear } \\
\text { why monthly drinking is } \\
\text { categorised as occasionally } \\
\text { for example. How was } \\
\text { amount measured and how } \\
\text { does this fit with other } \\
\text { similar adolescent } \\
\text { measures? Was it units? } \\
\text { drinks? and what was the } \\
\text { time frame - typical } \\
\text { occasion?, in the last } \\
\text { month? The reader has to } \\
\text { look at the table in the } \\
\text { results section to try to } \\
\text { make sense of this. }\end{array}$ & $\begin{array}{l}\text { The Likert scale was based on existing measures } \\
\text { of frequency (Livingston et al., } 2010 \text { \& Engels \& } \\
\text { Knibbe, 2000), which were adapted based on } \\
\text { the recommendations from the public health } \\
\text { dept who commissioned the work. We have } \\
\text { referenced the measures now and added as a } \\
\text { limitation that the scale would have benefitted } \\
\text { from more being better aligned with existing } \\
\text { measures of adolescent drinking. } \\
\text { Number of glasses of alcohol (drinks) was used } \\
\text { to measure amount consumed, in line with } \\
\text { previous research (Engels et al, 2007) for which } \\
\text { a reference has now been included. It is } \\
\text { recognised that units is a far more accurate } \\
\text { measure, however the pilot study indicated } \\
\text { that parents struggled to understand and } \\
\text { accurately calculate units, therefore number of } \\
\text { drinks was used as per similar studies. This has } \\
\text { now been explained. }\end{array}$ \\
\hline 6 & $\begin{array}{l}\text { It was not clear why some } \\
\text { items were picked out } \\
\text { within the text and other } \\
\text { items were not, perhaps } \\
\text { this could be clarified. }\end{array}$ & $\begin{array}{l}\text { We have added in the results and discussion, } \\
\text { more inclusion of the other significant findings } \\
\text { that were not discussed. }\end{array}$ \\
\hline
\end{tabular}


The authors agree and this has been added to the limitations. significant results and this could have been due to the design of the questionnaire and questions that were asked - as stated previously you included a measure that lumped occasional and monthly drinking in the same category and there is a big difference between regular monthly drinkers and those that might drink on special occasions.

8 A definition for bingeing is now included but needed to be justified with reference to literature. The definition of a binge of heavy episodic drinking in this age group varies but it is generally reported that 5 drinks would be considered a 'binge' in adolescent populations. Also the definition of heavy drinking for days or weeks is indicative of more problematic drinking and may have biased the results somewhat in terms of social desirability. These points needed to be considered more fully as limitations to the present study.

9 There is a general discussion around the potential implications and suggestions are made for future research, but findings could be more explicitly evaluated in light of the literature as a whole and linked more clearly to
It was requested that the authors use the definition agreed by the public health dept who commissioned the research, however we agree that the standard is in fact an average of 5 drinks, therefore we have added this as a limitation.

We have added in the limitations the potential impact on the findings of having a definition of binge drinking that does not align with other existing measures used in the adolescent population.

We have attempted to link the findings more clearly to the literature and to the introduction, although a significant proportion of the discussion was based on unexpected findings therefore this is not always possible. We feel that what is discussed relates to the findings and includes evidence in the literature. 


\begin{tabular}{|c|c|c|}
\hline & $\begin{array}{l}\text { the introduction. Many of } \\
\text { the points made lack } \\
\text { reference to literature or } \\
\text { theory. }\end{array}$ & $\begin{array}{l}\text { We are unclear about the comment regarding } \\
\text { points in the discussion not being linked to } \\
\text { theory or the literature. The only statements } \\
\text { that are not linked to the literature are ideas } \\
\text { put forward by the authors. We did not identify } \\
\text { the need to apply any theory beyond what is } \\
\text { mentioned- e.g. cognitive dissonance theory, } \\
\text { although of course this could be explored } \\
\text { further, however the word count would not } \\
\text { allow. }\end{array}$ \\
\hline 10 & $\begin{array}{l}\text { Although new information } \\
\text { has been added to the } \\
\text { discussion based on } \\
\text { previous reviewers } \\
\text { comments, the links to the } \\
\text { content are not always } \\
\text { clear. Line } 27 \text { for example } \\
\text { needs greater clarity are } \\
\text { you suggesting here that } \\
\text { the information available is } \\
\text { ambiguous and this might } \\
\text { explain why parent's also } \\
\text { didn't understand the risk? }\end{array}$ & $\begin{array}{l}\text { We are not sure what the reviewer requires } \\
\text { here. The discussion relates to the results and is } \\
\text { supported by the literature so we are unclear } \\
\text { about what we could do to rectify this further, } \\
\text { although some content has been added (see } \\
\text { highlighted text). } \\
\text { The authors are unclear regarding this point in } \\
\text { relation to Line } 27 \text { in the discussion. The } \\
\text { authors are stating that asides the risk to } \\
\text { mental health and drugs, recognising other } \\
\text { risks associated with alcohol was evident. We } \\
\text { cannot infer whether information given by } \\
\text { public health etc is ambiguous, lacking or } \\
\text { misinterpreted as this was not measured. } \\
\text { Apologies if we have misinterpreted the } \\
\text { reviewer comment here. }\end{array}$ \\
\hline 11 & $\begin{array}{l}\text { line } 48 \text { - or it may be based } \\
\text { on their own past } \\
\text { experiences of when they } \\
\text { were young (this would tie } \\
\text { in with the way beliefs are } \\
\text { formed). it is a shame that } \\
\text { parents' own drinking } \\
\text { behaviour was not } \\
\text { measured or discussed. }\end{array}$ & $\begin{array}{l}\text { The authors agree and have now added this } \\
\text { point. } \\
\text { We have now added the value of having } \\
\text { measured parental drinking behaviour in the } \\
\text { limitations. }\end{array}$ \\
\hline 12 & $\begin{array}{l}\text { The most significant finding } \\
\text { seems to be the view that } \\
\text { alcohol use is part of } \\
\text { growing up. There has been } \\
\text { some attempt made to } \\
\text { consider how this could be } \\
\text { addressed but the idea of }\end{array}$ & $\begin{array}{l}\text { The concept of re-framing has been described } \\
\text { and related to the literature. There was limited } \\
\text { evidence that the authors could find so the } \\
\text { example relates to obesity. } \\
\text { The authors chose not to delve into the } \\
\text { literature on alcohol norms interventions as }\end{array}$ \\
\hline
\end{tabular}


this is so substantive and not feasible within the word count. thy evidence. If you are considering normative beliefs then it may be useful to consider the body of literature on alcohol norms and intervention to address norms such as normative feedback.

13 The main limitation seems to be the questionnaire design in terms of academic rigour and this could be discussed.

14 More information about the feedback after the pilot and how you gathered the feedback and adjusted the questionnaire would be useful.

15 There is some lack of clarity in line 15 - what finding are you referring to? - you are stating that there are no differences and yet suggest that older parents might have greater life experience and so this is confusing.

16 line 44 - it is not clear what We have clarified that we mean causality here. you mean by direction of association - do you mean causality?

17 line 58 - the citation for $\quad$ This has now been added. Jones and Francis needs the year adding.
There was no differences between parental reports on younger and older children. However there were differences in reporting from younger and older parents on child drinking behaviour. We have italicised this to make it more clear that it refers to two separate findings, and now stated as such 